\section{Dantes Plads: Utzon-Frank, Carpeaux, Rodin. Oplæg til en litterær skulpturvandring ved Glyptoteket}

Af forskningsstipendiat Ole Meyer

$\mathrm{D}$ et siges at Dante er den klassiske forfatter der er bedst kendt af københavnske taxachauffører.

Det skyldes dog ikke i første række hans værk, men den omstændighed at han har givet navn til arealet mellem $\mathrm{Ny}$ Carlsberg Glyptotek og hjørnet af Nationalmuséet: Dantes Plads. Forbindelsen til den italienske digter fremgår dels af Beatrice-statuen udenfor (af Einar Utzon-Frank, 1924), opstillet på en romersk søjle midt i trafikken, dels, og navnlig, af selve muséets samlinger, især af Rodinskulpturer. Disse kan beses i Rodin-salen til højre efter indgangen, og her møder man faktisk Dante selv, nemlig i form af Grubleren (Le Penseur). På Edward Steichens berømte fotografi fra 1903 (se Magasins forside) ses figuren til venstre, modstillet billedhuggeren selv til højre; i baggrunden ses monumentet over Victor Hugo, ligesom i Glyptotekets nuværende opstilling.

Den grublende mand er vel Rodins mest alment kendte værk. Figuren skulle egentlig være indgåer i den store Helvedsport (Porte de l'Enfer), der var en bestilling fra 1880 til et planlagt men aldrig realiseret kunstindustrimuseưm (Musée des Arts Décoratifs) i Paris i nærheden af Louvre - netop dér hvor det nuværende Musée d'Orsay er indrettet $i$ hovedbygningen fra den banegård som kom i stedet. Bestillingen lød dengang på en udsmykket indgangsport, og idéen om at vælge Dantes Inferno som motiv kom fra Rodin selv, der var ivrig læser af Den Guddommelige Komedie, og efter sigende til stadighed bar værket på sig i jakkelommen, velsagtens $\mathrm{i}$ en fransk oversættelse. (Hans eksemplar, der sandsynligvis har indeholdt de første skitser og notater er desværre gået tabt). En yderligere inspiration var Ghibertis broncedøre fra dåbskapellet i Firenze, som Rodin havde set på sin italiensrejse nogle år forinden og hvis generelle komposition med inddeling i otte felter fordelt på to døre genfindes i de første stadier af porten.

Selve idéen om en port refererer i øvrigt direkte til begyndelsen af tredje sang i Dantes Inferno, med den berømte indskrift der fortæller hvad jegpersonen "Dante" og hans fører Vergilius skal igennem:

“JEG FØRER IND TIL DEN FORPINTE BY, JEG FØRER IND TIL UOPHØRLIG GRAD. JEG FØRER IND TIL DET FORDØMTE FOLK. RETFÆRDIGHED RØRTE MIN HØJE SKABER; MIG SKABTE DEN GUDDOMMELIGE ALMAGT, DEN STØRSTE VIISDOM OG DEN FØRSTE KARLIGHED.

ALT DER FØR MIG BLEV SKABT, SKABTES SOM EVIGT, SA EVIGT SOM JEG SELV, DER VARER EVIGT. LAD ALT HÁB FARE, I DER HER GAR IND".

En version samlet efter Rodins død kan i dag ses i gips på Musée d'Orsay i Paris, og i afstøbning på Musée Rodin samt i Kunsthaus Zürich; den måler 7,5 
meter i højden, og er gengivet på Glyptotekets tekstark, der er tilgængeligt i Rodin-salen.

Dørene kan her ikke mere åbnes, fordi der ikke længere er tale om en port men snarere om et billede af en port: en sammenstilling af skulpturer og relieffer anbragt i og på en ramme der henviser til den oprindelige idé til udformningen af muséets indgangsparti. Som det fremgår (s. 5), er Grubleren placeret centralt i tværfeltet foroven. Det er ikke et portræt af Dante som man mente han så ud, men en almengjort fremstilling af forfatteren eller fortælleren der grubler over sit værk, en fortælling som han på én gang er en del af og står uden for. Med andre ord: et portrait d'artiste, der med henblik på udtrykket også kan tolkes som Rodin selv, ihvertfald sådan som Steichen har set ham i 1903. (Samme tanke, at figuren kan tolkes som kunstnerisk selvportræt, blev fanget af forfatteren George Bernard Shaw, der havde siddet model for Rodin til en portretbuste, og som i lighed med Strindberg og Munch eksperimenterede med fotografi omkring århundredskriftet: et foto fra Shaws hånd, gengivet i Hélène Pinets bog om Rodin, viser Shaw selv, nøgen, i grublerpositur).

Om det nu er tilfældigt eller ej: i selvsamme stilling, grublende med hånden under kind, afbildes forfatteren Dante på et norditaliensk Komediehåndskrift fra o. 1400, der siden 1700tallet har befundet sig i Det Kongelige Biblioteks eje.

Rodin har naturligvis ikke set dette billede, omend han teoretisk kunne have set en tilsvarende fremstilling $\mathrm{i}$ et noget ældre håndskrift der nu befinder sig i Firenze. En fælles forudsætning kan være den figur der ikonografisk kaldes Melancholia, kendt især fra Dürers allegoriske stik. (En tidsmæssigt og geografisk mere nærliggende inspiration for Rodin er muligvis Carpeaux' Ugolino-statue, som skal afslutte vores vandring i samlingerne). Hvorom alting er, illustrerer billedet i håndskriftet Komediens begyndelse, hvor jeg-personen er faret vild i sit liv, og hvori fortællingens grundtone og -struktur fremlægges:

\section{Midtvejs på vores vandring gennem livet befandt jeg mig i morke, dybe skove,} forvildet fra den vej jeg burde folge. Hvor tungt og plagsomt er det sted at skildre: så vild og ufremkommeligt at tanken genfoder frygten som jeg folte dengang! (...) Hvordan jeg kom derind, er svart at sige ...

Som det ses, beretter teksten både om oplevelsen i fortiden, og om hvor svært det er at fortælle om den. På litteraturvidenskabeligt taler man om metalitteraritet, et træk man ellers først finder - eller først er blevet opmærksom på - i moderne eller modernistisk litteratur.

Man skal være opmærksom på at Dantes tekst har tre fortælleniveauer, hvoraf Grubleren illustrerer det første og øverste: fortællerens grublen over sin egen fortælling. Det er det niveau både den anonyme illustrator fra 0.1400 og Rodin i 1880'erne har fokuseret på, uafhængigt af hinanden: altså digteren der reflekterer over sit værk og over problemerne med at give det en form.

Nedenunder dette har vi dernæst det andet niveau, nemlig det der 


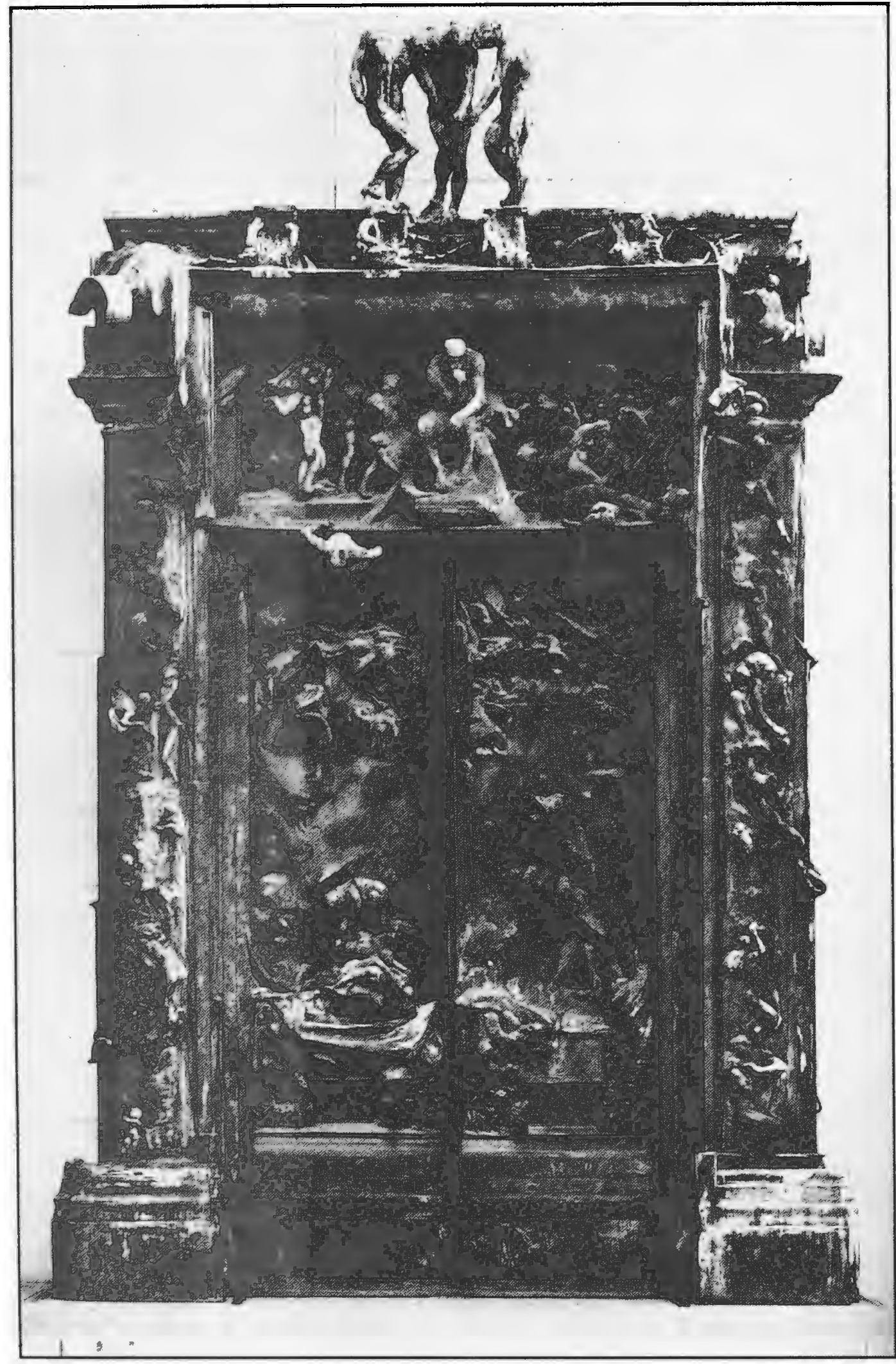

Auguste Rodin, Helvedsporten, foto af afstobning i Kunstmuseum Zürich. 


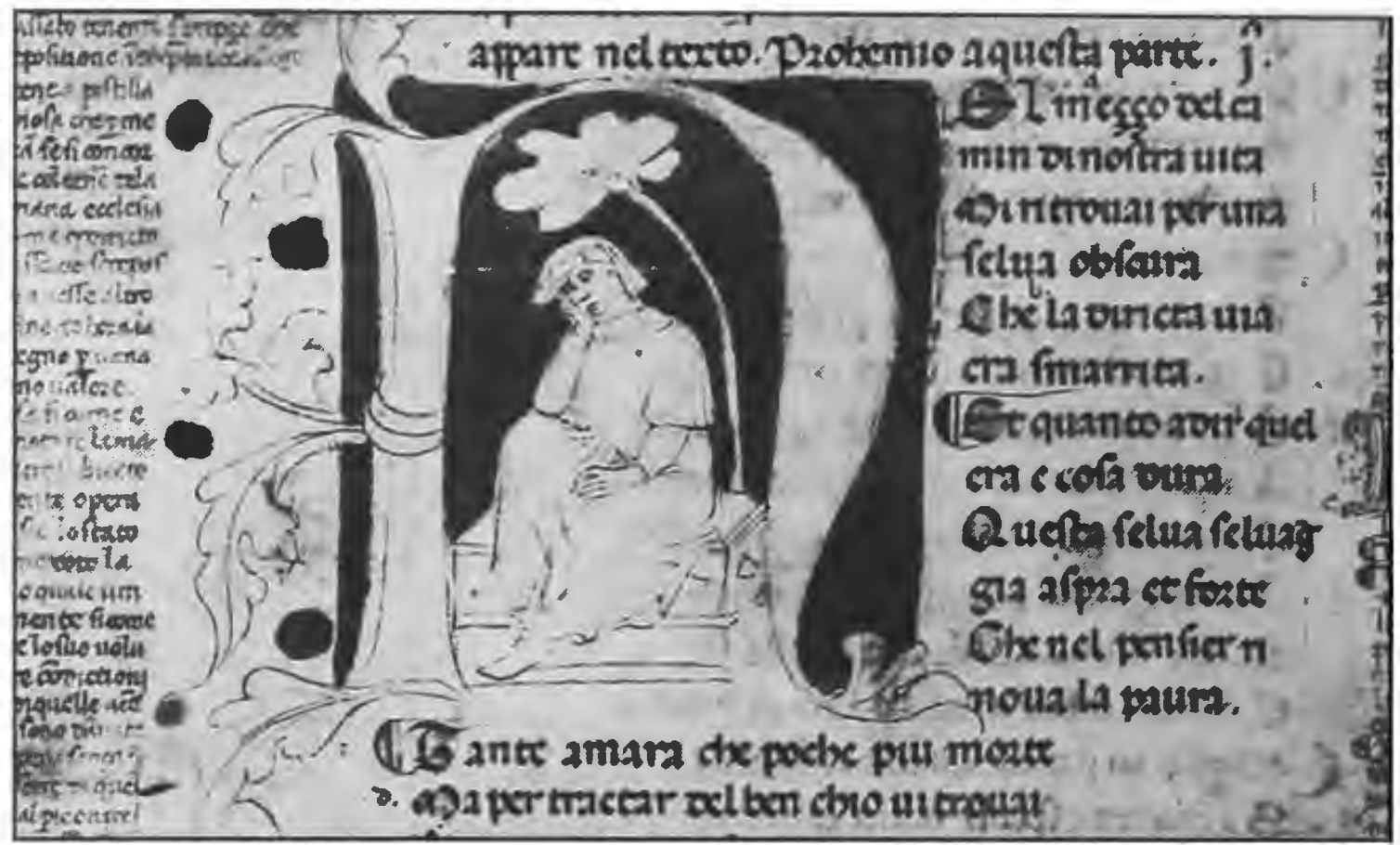

Thott 411, p. 1 r (udsnit). Håndskriftafdelingen.

fortælles om. Dette plan udgøres af jegfortællerens oplevelser som person på vandring gennem dødsrigerne: altså f.eks. skildringen af skoven og vejen ind i/ud af den.

Endelig udgøres det tredje, nederste niveau af de fortællinger der fortælles til jeg-personen af de personer han møder, længere fremmme i Helvede og de følgende dødsriger.

Alle tre niveauer er til stede i Helvedsporten, men vel at mærke delvis blandet sammen, som de også er det $\mathrm{i}$ Dantes egen fortælling. ( $P a ̊$ tilsvarende vis finder man $\mathrm{i} ø v r i g t$ nu og da i samtidig, gotisk billedkunst eksempler på overskridelse af billedernes rammer og fortalte niveauer; et forhold den svenske kunsthistoriker Sven Sandström træffende har kaldt "levels of unreality". Det er noget lignende beskueren i dag oplever overfor Rodins port).
$H$ Telvedsporten blev som sagt aldrig færdig. Årsagen var ikke kun at bestillingen faldt bort da muse umsprojektet blev skrinlagt, eftersom Rodin blev ved med at arbejde på idéen. Porten fik sit således sit eget liv, og løsgjorde sig både fra anledningen og fra forlægget, for at blive til et uafslutteligt projekt for ham, en fortælling som han ikke kunne slippe, fordi den ikke ville falde til ro i en afsluttet form. Figurerne (med eller uden forlæg i Komedien) blev med skiftevis taget ud af og sat ind i helhedskompositionen, der således var under stadig forvandling.

Denne dynamik forbinder Rodin med Dante: ligesom flere skikkelser i Den Guddommelige Komedie har en tendens til at træde ud af rammen og insistere på deres egen historie, voksede også Helvedsportens enkelte figurer så at sige fri af helheden og blev til fritstående 


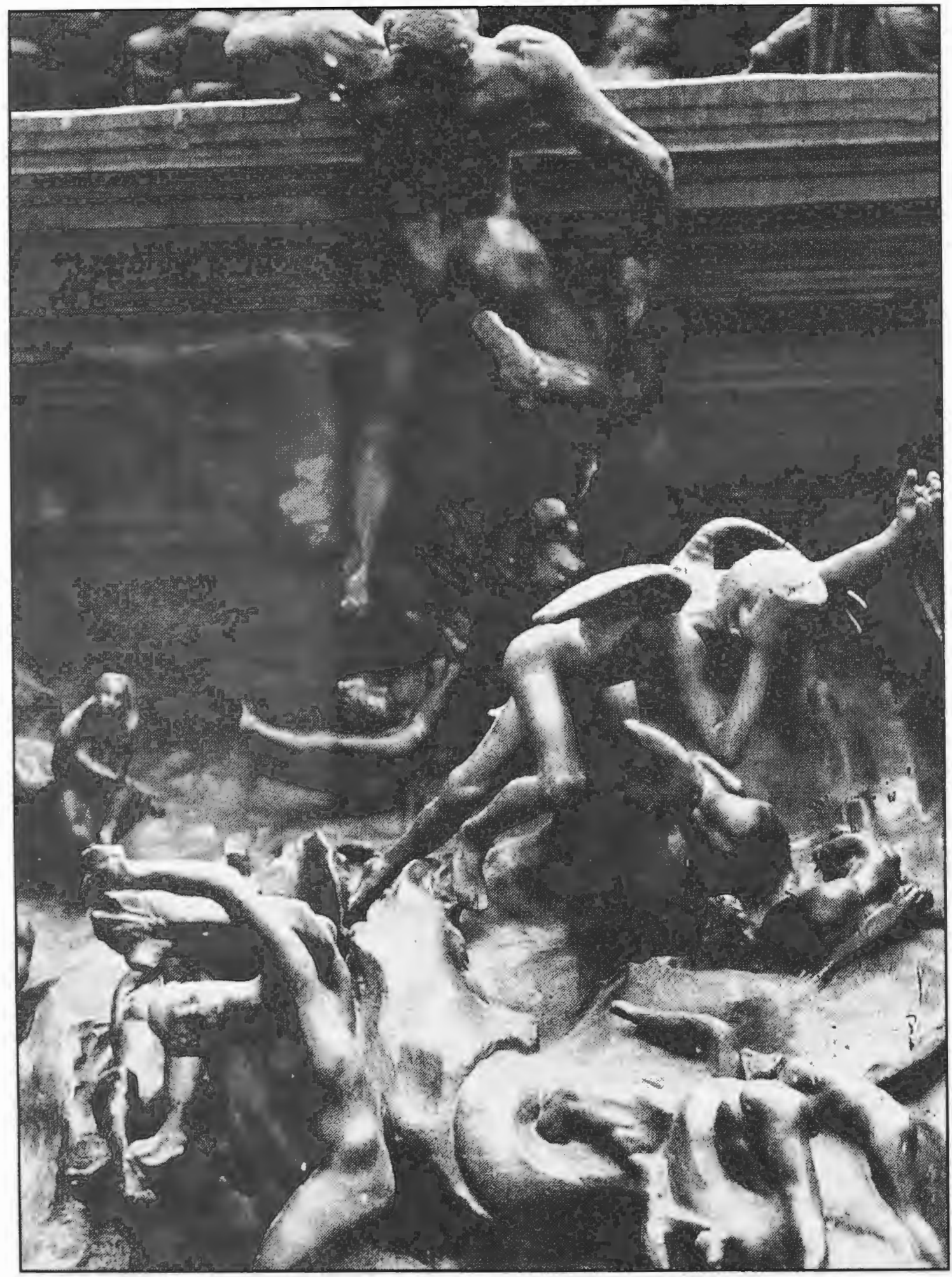

Udsnit af Helvedsporten, fra Hélène Pinet, Rodin, The Hands of Genius, s. 40. 


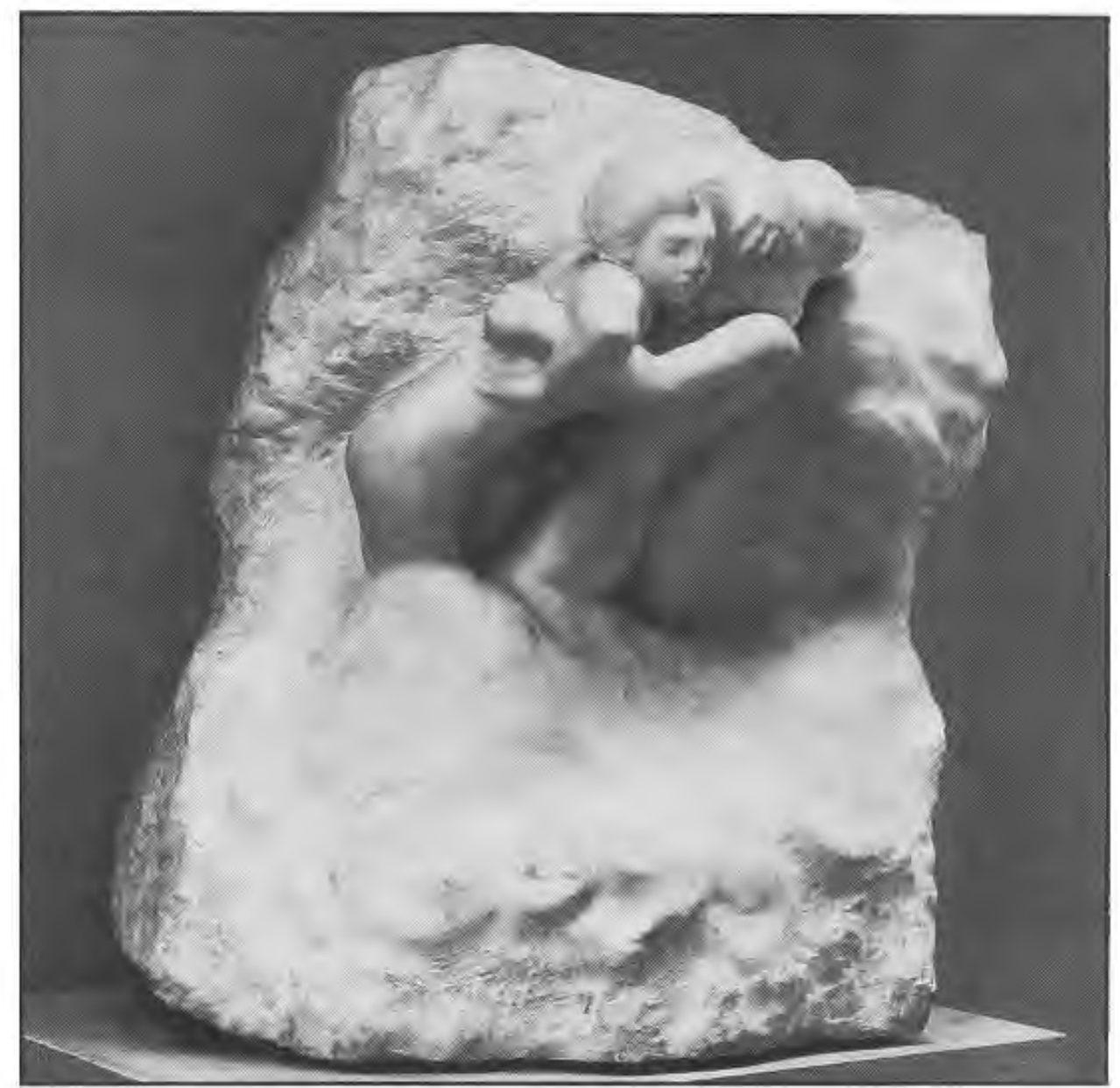

Paolo og Francesca. Hugget senest 1907. Ny Carlsberg Glyptotek. Kobenhaun.

værker, der i dag hører til Rodins allermest kendte.

I kraft af spændingen mellem helhed og del, dvs. mellem det overordnede udsagn og de enkelte fortællinger, blev Rodins reliefportal mere trofast mod anden og tonen i Komedien end noget andet billedværk skabt mellem manierisme og modernisme (en oplagt sammenligningsidé fra omtrent samme periode er Gustave Dorés prægtige og teksttro illustrationer, der bl.a. kan beses i Ebbe Kløvedal Reichs smukt udstyrede genfortælling fra 1991).

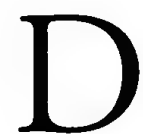

ér hvor Dantes port bærer en indskrift, har Rodin altså anbragt Dante selv (eller sig selv, om man vil) grublende over sit værk. Omkring og under ham myldrer det med figurer i forskellige grader af fortabelse og fortvivlelse, hvoraf en del kan ses på Glyptoteket. De egentlige pinsler begynder hos Dante i anden helvedskreds; her straffes ægteskabsbrydere og andre vellystige ved $\mathrm{i}$ evighed at blive pisket rundt af en voldsom storm, som psykologisk og moralsk er et billede på den synd de selv valgte at knytte deres liv til: 


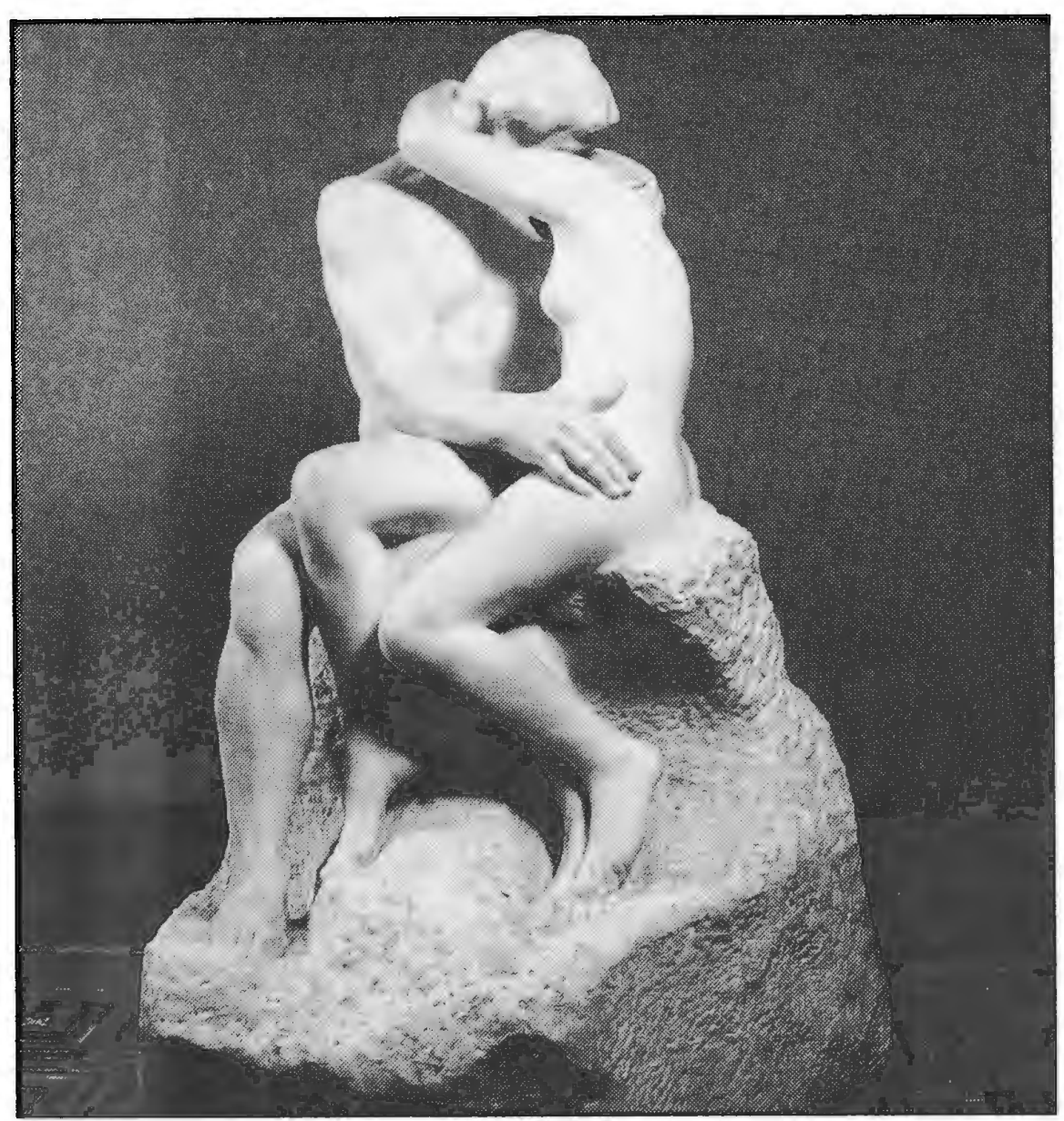

Kysset. Hugget 1901-03. Ny Carlsberg Glyptotek. København.

Og uden hvile blaser helvedsstormen og river sjale med sig, der må folge

den hvor den vil, imens de hvirvles, piskes, mishandles, gennemruskes; og med véräb, med klage, hulken, moder de dens rasen, og raser selv mod Gud og hans forordning.

(Inf. V, 30-36)

Vi er her på fortællingens andet, og dominerende niveau: jeg-personens oplevelser. Dante får i stormen øje på kærlighedsparret Paolo og Francesca, der er havnet her efter sammen at være blevet overrasket af hendes ægtemand og hans bror - der dræbte dem begge; et motiv der i øvrigt blev flittigt udnyttet i tidlig fransk 1800-talsmaleri, bl.a. af Ingres. Som det ses, har Rodin på nærmest michelangelosk manér hugget de to skikkelser ud af stenen/stormskyen, som en mellemting mellem relief og fritstående skulptur.

Den samme historie er også udgangspunktet for et af Rodins mest populære værker, Kysset, der kom i vælten som kaminskulptur omkring århundredskiftet. Rodin selv selv havde vistnok et mere køligt forhold til gruppen, men smuk er den jo, mente han også selv. Brygger Jacobsen måtte da og- 


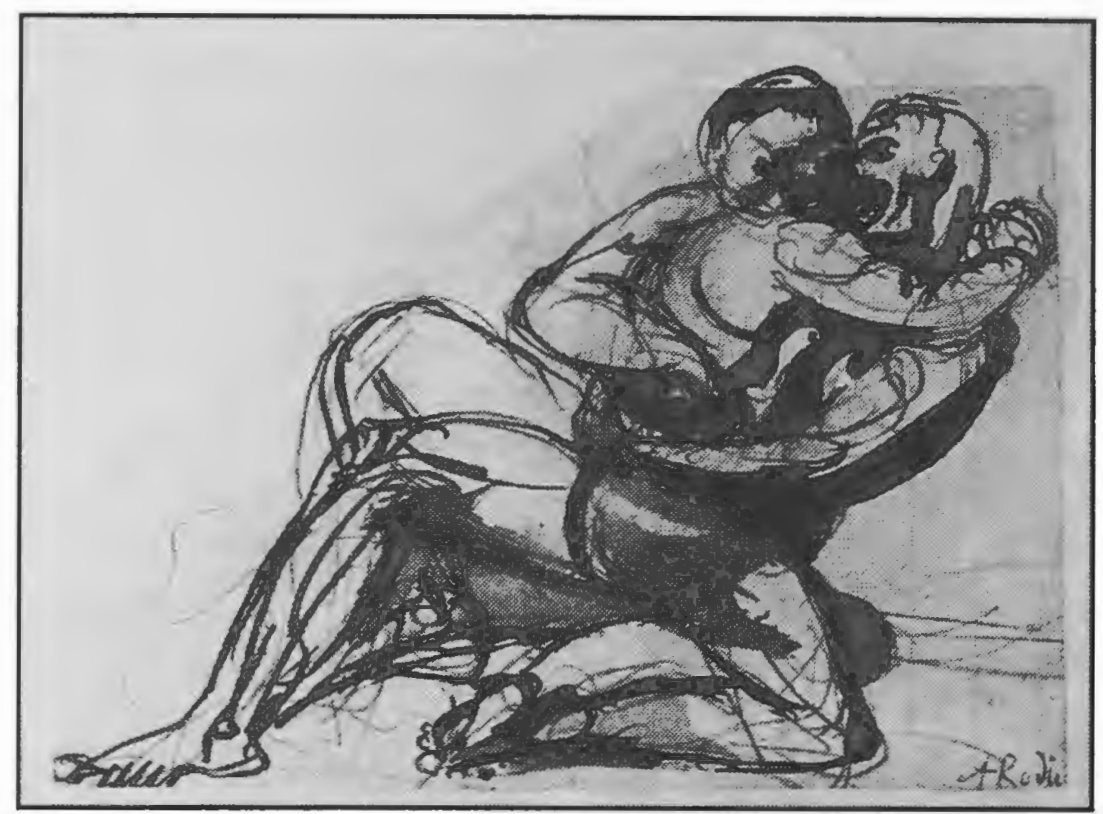

Rodin, laveret tegning, ca. 1880. Ny Carlsberg Glyptotek. Kobenhavn.

så absolut have den, og stillede helt specifikke krav til udførelsens finish, krav som Rodin beredvilligt gik ind på.

Der er her tale om en fritstående skulpturgruppe, der oprindelig skulle være indgået $\mathrm{i}$ portalen som en illustration af fortællingens tredje niveau, altså den indlejrede fortælling fra de personer jeg-fortælleren møder på sin vandring og beder om at fortælle om deres liv på Jorden, især om hvorfor de er havnet netop hvor de er. (Man kan her notere sig at dette niveau, der flere steder har karakter af selvstændige fortællinger $\mathrm{i}$ den store fortælling, dominerer i Dantebillederne efter middelalderens slutning. Hos de middelalderlige illustratorer er det derimod temmelig sjældent forekommende, idet disse $\mathrm{i}$ almindelighed holder sig til niveau 2, dog af og til med en indledningsvis markering af niveau 1 i form af en skrivende eller som ovenfor anført tænkende/drømmende Dante).
Som svar på et spørgsmål fra jeg-personen fortæller Francesca nu sin historie; vi bevæger os dermed fra 2. til 3. fortælleniveau:

...Men sig mig: da I hver for sig blot sukked, hvordan gik det da til at karligheden lod jer erkende langslen jeres skjulte langsel?" Hun svared: "Der er ingen større smerte end midt $i$ ulykken at måtte mindes den lykke som forsvandt: det véd din lerer.

Men siden du så ivrigt soger roden til vores karlighed, vil jeg fortalle hvordan det hendte, hvis jeg kan for tårer: $V i$ leste $i$ en bog en dag, uskyldigt, om Lancelot, hvor karligheden greb ham; vi var alene, aned intet uräd.

$O g$ lesningen tvang vores ojne sammen mer end én gang, og fik os til at blegne, indtil et enkelt sted fik os besejret: vi laste om hvordan de laber modtes som lange havde villet det - da kyssed min ven, fra hvem jeg aldrig mere skilles, min mund, imens han skalved, sitred ved det. En kobler blev den bog, og ham der skrev den: vi leste ikke mere i den dén dag." 
Rodins billedgruppe viser kvinden som den aktive, manden som den mere tøvende; under hans (Paolos) hvilende venstre hånd ses, antydet $\mathrm{i}$ marmoret, omridset af den bog de begge har læst $\mathrm{i}$, nemlig ridderromanen om den fatale kærlighed mellem kong Arthurs bedste ridder Lancelot og hans dronning Guinevere. Det romantiske tristan-lignende motiv var en af middelalderens populæreste fortællinger, der $\mathrm{i}$ nutiden er bedst kendt fra filmen First (K)night - men vist kun antydet i den mere artige Prins Valiant?

$$
\text { I øvrigt er Glyptoteket også i }
$$

besiddelse af en skitse til dette motiv, en pennetegning som desværre ikke er udstillet, men som kan og vil noget i sanselighed, at dømme efter gengivelsen $i$ Hélène Pinets bog om Rodin, der fås til en billig penge i muséets kiosk. Med denne bog - eller med nærværende nummer af Magasin — $\mathrm{i}$ hånden kan man siden gå ned i i kælderetagen på Thorvaldsens museum et par minutters gang fra Glyptoteket, og sammenligne Rodins dynamiske tegning med den danske guldalderkunstners mere statuarisk kølige blyantstegning over samme motiv.
$\mathrm{D}$ e tre sidste skulpturer i Rodinrummet der har tilknytning til Helvedesporten er henholdsvis Den fortabte søn, Skyggen og Karyatiden. De forholder sig alle mere perifert til teksten, men er vigtige i Rodins komposition ved at de markerer tyngde og fald såvel som det modsatte, nemlig en stræben opefter : kræfter der også er afgørende på spil i Dantes Komedie.

Karyatiden er som motiv formentlig ikke hentet fra Helvede men derimod fra Komediens anden del, Purgatoriet (som lidt misvisende kaldes for Skarsilden i de hidtidige danske oversættelser). I den første, nederste cirkel af det kegleformede Renselsesbjerg sones hovmodets synd således:

Som man fra tid til anden ser en hvalving der bares af figurer skabt som mennesker, men presset sammen, kne mod bryst; og synet af det der ikke er, gor en urolig,

som vár det til, og ikke kun et billed

- såjeg dem nu, da de var kommet narmere. Nok gik de ikke alle lige krumme: nogle bar mere, mens andre bar mindre, men selv de mest tålmodige gik gradende som om de sagde: "Nu kan jeg ikke mere".

(Pg.X, slutningen)

Denne canto indeholder også en beskrivelse af Forsynets egen skulpturkunst, der er placeret som billedfrise i klippen ved siden af den sti der fører de sonende op mod frelsen; fortællingen indledes med en gengivelse af bebudelsesenglen. Man kan tænke sig at billedhuggeren Rodin har fæestet sig ved en passage som den følgende: 


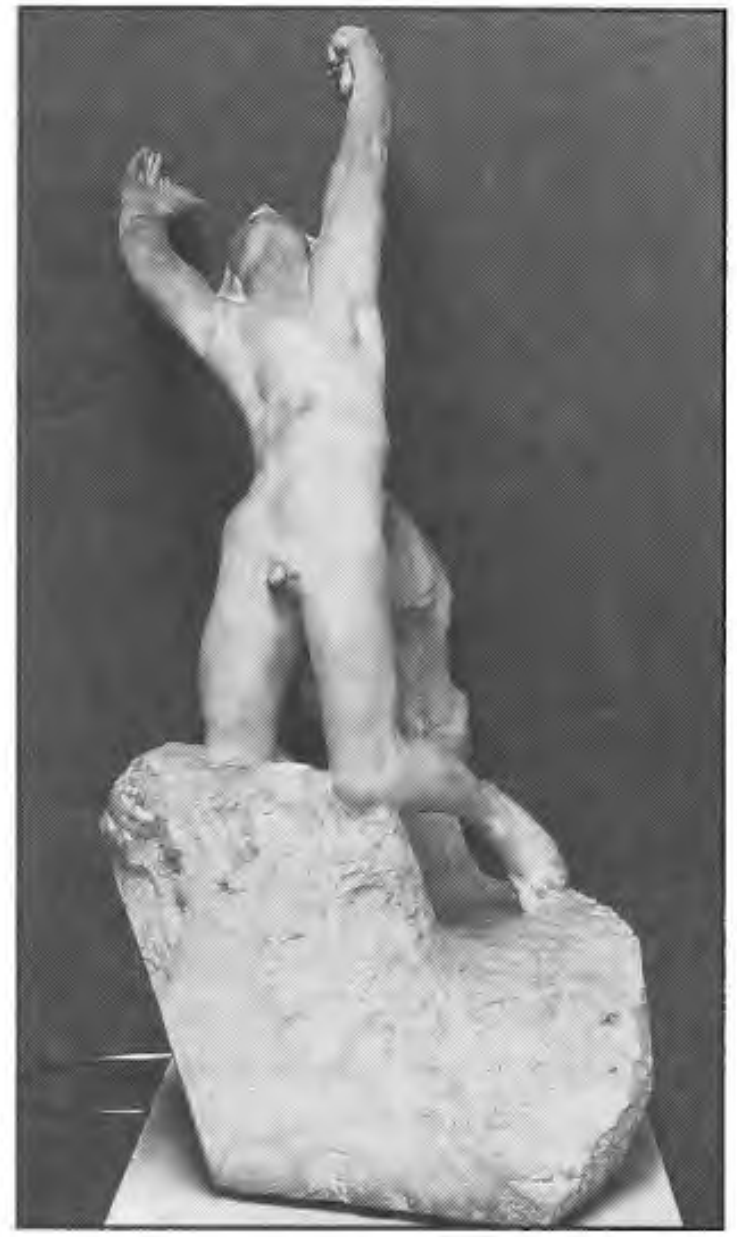

Den fortabte sjæl el. søn. Hugget 1899 (?). Ny Carlsberg Glyptotek. Kobenhavn.

Og vores fodder havde endnu ikke taget de forste skridt, da jeg på klippen, der nederst var mindre stejl, så en friseaf billedrelieffer $i$ hvid marmor der overgik hvad selve Polykleitos, ja selv naturen ville kunne skabe.

Den engel der på Jord forkyndte freden, den fred vi havde bedt for gennem lange og kummerfyldte àr, den fred der abned de lange stengte himmelrigets porte dér stod han, ligesom andet ind $i$ klippen, så at man nasten troede at han talte.

(vv.18-39)

Længere fremme, i 12. canto, fortsættes beskrivelsen, og her drejer det sig om relieffer med en voldsomhed og dynamik som var de Rodins egne:

Som gravstene $i$ kirkegulvet viser os andre huad de dode var $i$ live, så dette ikke glemmes af de levende,

(...) så jeg nu dér, men langt mere livagtigt, udgået af en storre kunstners hander, en billedbog $i$ hele vejens bredde.

Dér så jeg til den ene side ham som blev skabt mer fuldkommen end andre skabninger, nedstyrtende, som lyn falder fra himlen; og til den anden side Briaréus, der lå på jorden i sin dodskamp, ramt af den Himlens pil der traf ham fra Olympen; jeg så Timbraus, jeg så Mars og Pallas bevabnede ved deres faders side, blandt spredte, livlose titanerlemmer...

(vv.1-78)

Dette kan minde om skildringer af besøg i Rodins eget atelier, hvor over 200 dele af skulpturer fra Helvedsporten lå spredt som disjecta membra på borde og hylder. Fragmenterne fungerede som kunstnerens inspirationsarkiv, og blev fra tid til anden sat sammen på nye måder, enten som dele af Portens aldrig afsluttede helhed, eller som helt nye skulpturer eller skulpturgrupper.

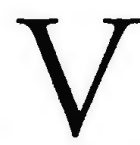
i slutter af med pragtstykket Ugolino, som Glyptoteket desværre ikke har i Rodins version. Man kan forestille sig at den ikke var tilstrækkeligt opbyggelig for Carl Jacobsen, der $\mathrm{i}$ hvert fald ikke interesserede sig for Helvedsporten som sådan, men alene bestilte enkelte, mere salonagtige skulpturer udgået fra den, såsom Kysset. Ikke desto mindre er det værd at omtale Rodins Ugolino inden vi forlader Rodinrummet 
Karyatide der segner under $\sin$ byrde. Hugget 1907 (?). Ny Carlsberg Glyptotek. Kobenhavn.

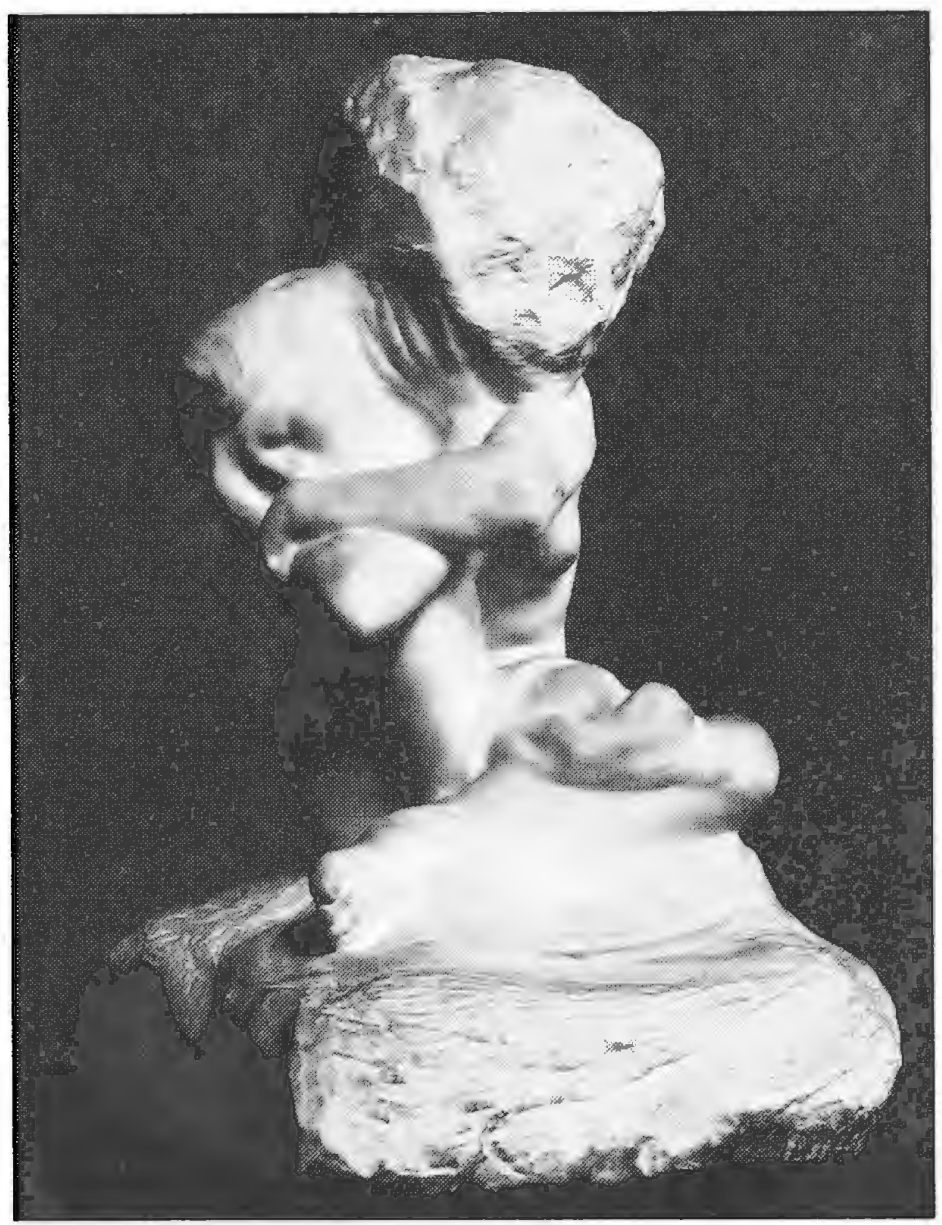

for til slut at betragte en lidt tidligere version af motivet, nemlig Carpeaux' værk, som Rodin kendte og forholdt sig til.

Først lidt baggrund: motivet er fra den nederste del af Dantes Inferno, Canto XXXIII. Personen, grev Ugolino della Gherardesca og Pisas tidligere hersker, led sammen med sine sønner en frygtelig død i det såkald te hungertårn i Pisa, efter at være faldet som offer for en list udtænkt af hans modstander, ærkebiskop Ruggieri. Som alle andre helvedsindvånere befinder Ugolino sig dér hvor han gør på grund af en specifik synd, der ikke nødvendigvis har noget at gøre med dén historie Dante lader ham selv fortælle. Han introduceres i Komedien på 2. fortælleniveau, dybest nede i Helvede, hvis bund udgøres af en umådelig issø, hvor forrædere mod slægt og fædreland er indefrosset. På deres vej ind mod midten, hvor selveste Lucifer (den nedstyrtede lysengel, Satan selv) sidder fast i isen, blir de to vandrere, jeg-personen og hans fører Vergilius, opmærksomme på noget sælsomt:

(...) Men vi var allerede gået videre, da jeg så to, $i$ ét hul, frosset sammen sà hovedet af den ene var en hatte for ham ved siden af, som han fortered så grädigt som en sulten sluger brodet: han satte tanderne $i$ dér hvor hjernen og nakken modes; og han gnaved grädigt, (...) $i$ kraniet og de blode dele om det. 


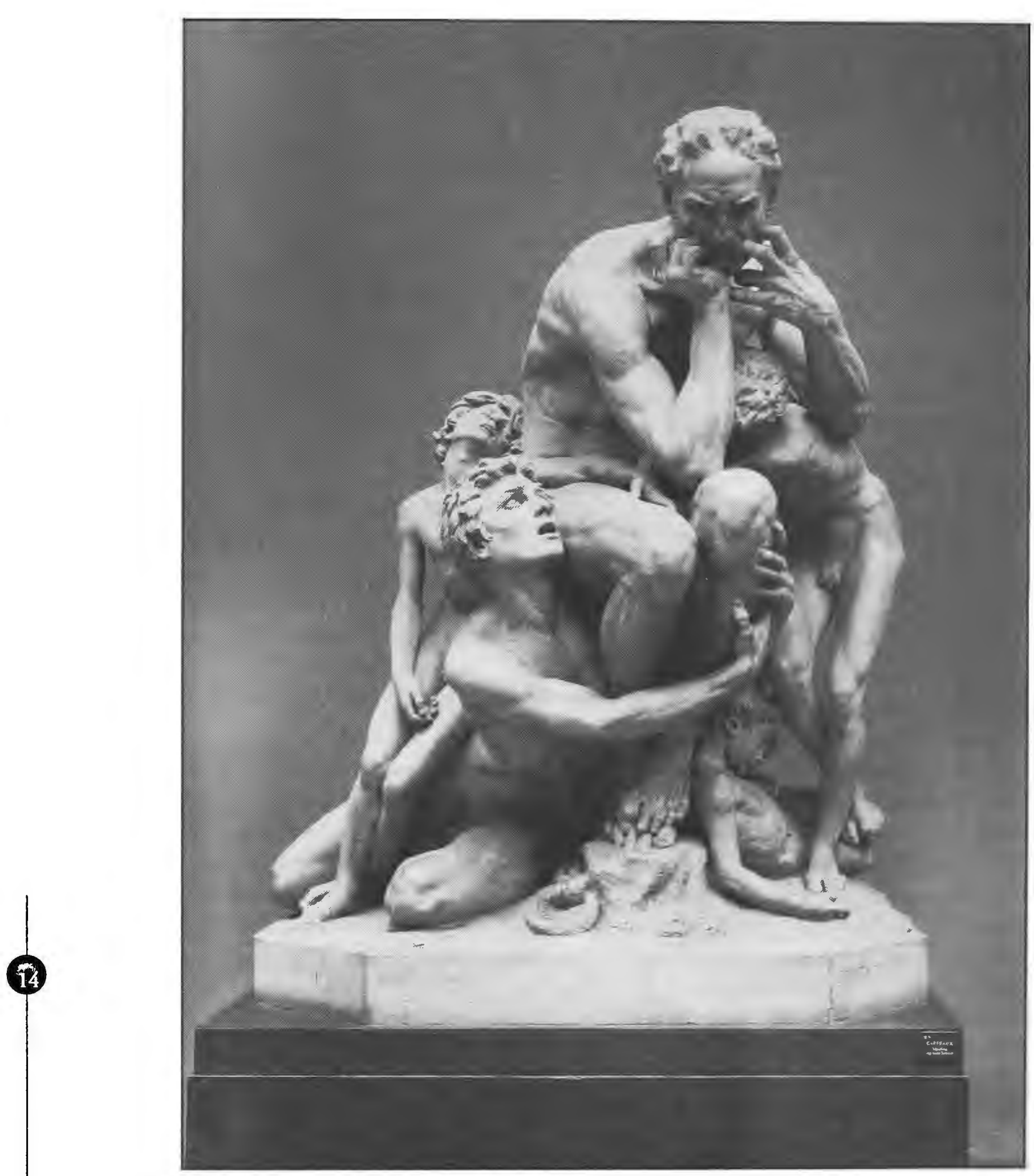

Jean-Baptiste Carpeaux, Ugolino og hans sønner, 1861, terrakottaversion 1873. Ny Carlsberg Glyptotek. Kobenhavn. 
Vandreren udspørger personen om hvem han er og hvad grunden er til det had han synes at nære til den anden. Svaret, der er en af Komediens store passager, indleder 33. og næstsidste helvedscanto, hvor vi bevæger os fra andet til tredje fortælleniveau, for til sidst igen at slutte på andet niveau. Ugolinos beretning følger her uden yderligere kommentarer:

\section{Han horte mig, og lofted munden op fra} sit grumme mältid, torred den i häret $p a ̊$ hovedet, der var søndergnavet bagfra, og sagde sa: "Du vil have mig til at vakke en smerte så fortvivlet at blot tanken knuger mit hjerte, for jeg taler om den.

Men dersom mine ord kan så et fro til en skandselsfrugt for ham jeg her forterer, da taler jeg, og grader mens jeg gor det. Jeg ved ikke hvem du er, eller hvordan $d u$ kom herned, men florentiner er $d u$, det horer jeg når blot du åbner munden.

Så vid da at jeg var grev Ugolino, og denne mand Ruggieri, arkebispen: hor nu hvorfor vi er sådan forbundne.

Hvordan jeg af hans snubed lod mig narre, og selv gik ind i falden, og at dét blev min dod, det ved du sikkert allerede; men hvad du ikke ved, og nappe aner, nemlig hvor härd og frygtelig min dod blev, skal du hore nu; dom så os imellem.

En lille sprakke i det morke bur som på grund af mig fik navnet Hungertårnet, hvad flere skal erfare - havde vist mig den ene måne aflose den anden; da kom den onde drom der flanged sloret for hvad der var $i$ vente: den mand her stod $i$ spidsen for en jagt, og havde sporet en hanulv og dens unger på det bjerg som skjuler for Lucca når man står i Pisa.

Forrest blandt jegerne havde han anbragt Gualandi med Sismondi og Lanfranchi, med magre, snu og veltranede hunde.
Efter et kort lob syntes far og unger kort tratte, og jeg så de skarpe tander bore sig ind og flanse deres flanker.

Jeg vågned kort for daggry, og da horte jeg mine sonner, som var sammen med mig, grade imens de bad om brod $i$ sovne.

Forhardet er du, hvis du ikke gruer ved det mit hjerte allerede aned! Hvis ikke nu, hvornår vil du da grade?

Nu var de vågnet; det var nar den tid hvor vi plejed at fä mad, men alle tonkte vi hver på vores drom, og aned uråd.

Da horte jeg hvordan de sommed doren til tairnet til forneden; jeg betragted bornenes ansigter, men lod som intet. Jeg grad ikke, men alt $i$ mig forstened. Dé grad; min lille Anselmuccio sagde: 'Hvad er der? Hvorfor ser du sådan ud, far?' Jeg svared ikke, og grad heller ikke, bele den dag, hele den nat der fulgte, indtil den naste dag oplyste verden.

En ussel stribe lys fandt vejen ind til det pinefulde fangsel, og jeg så da $i$ deres fire ansigter mit eget;

af smerte bed jeg begge mine hander, og de, der troede sulten drev mig til det, haved sig op, krob tattere, og sagde:

Far, det ville smerte os langt mindre hvis du spiser af os; du som har givet os dette arme kod, tag det tilbage!'

For deres skyld behersked jeg mig; hele den dag, og den der fulgte, tav vi - du hjertelose jord der ikke àbned dig!

Da vi var nået til det fjerde daggry kasted min Gaddo sig for mine fodder og sagde: 'Far, hvorfor hjalper du mig ikke?'

Dér dode han, og ligesom dú ser mig, så jeg dér de tre falde, én for én, mellem femte og sjette dag; $i$ blinde famled jeg over deres lig, og kaldte på dem $i$ endnu to dage - da gjorde sulten til slut hvad smerten ikke havde kunnet".

Han tav, og med skelende ojne gav han sig atter til at gnave hovedskallen med tander starke som en hunds mod benet.

(vv. 1-78) 
Som man ser, får vi ikke her nogen forklaring på hvorfor de to befinder sig $i$ isen som forrædere - at det for Ugolinos vedkommende skulle være hans straf for at have forgrebet sig på børnenes døde kroppe, som hævdet $\mathrm{i}$ Glyptotekets Fransk skulptur, s.82, kan i hvert fald ikke passe. Som man ser, står det ganske vist åbent $\mathrm{i}$ teksten om noget sådant kan være sket, men dette ville ikke i sig selv forklare placeringen, der må have at gøre med grevens (såvel som bispens) forvaltning af magten i Pisa $i$ deres velmagtsdage. Blot er dette skyldsspørgsmål ikke i fokus i fortællingen: kun indirekte, dels gennem placeringen af de to dødsfjender, dels ved en enkelt antydning senere i teksten, slås det fast at begge er syndere, velkendte af Dantes samtid, og anbragt nederst i Helvede af en højere retfærdighed, der ikke på dette sted problematiseres.

Hvorom alting er: historien blir et hit i 17-1800-tallet, litterært såvel som billedkunstnerisk. Vel at mærke Ugolinos egen historie, fortalt på fortællingens tredje niveau: man interesserer sig ikke for den synder $\mathrm{i}$ isen som jegfortælleren oplever, men derimod for det lidende og undertrykte individ, som han kommer til udtryk i sin egen historie, der nu læses løsrevet fra konteksten. Dette aspekt er helt fraværende i middelalderlige illustrationer til Komedien: blandt samtlige illuminerede håndskrifter findes der vistnok kun ét eksempel (fra midten af 1400-tallet, nu i British Museum ) på en illustration til Inferno XXXIII som bevæger sig fra 2. til 3. fortælleniveau, og altså helt eksakt viser hungerscenen i tårnet. Den scene som senere tiders læsere, digtere og illustratorer har opfattet som hovedpunktet.

Vi er vidner til et skift i fokus, fra middelalderens syndsbevidsthed til oplysningens og romantikkens individog frihedstænkning. Hos malerne Gainsborough og Füssli fra 1700-tallet, og siden, i 1800-tallet hos bl.a. Delacroix (billedet findes på Statens Museum for Kunst, omend for tiden utilgængeligt) er der fokus og lys på den uretfærdigt fængslede Ugolino midt i fængslets mørke, et heroisk offer for bispens lede rænker. Hermed blir historien til et udsagn i tidens antiklerikale og fritænkeriske kulturkamp, dvs. i frigørelsen fra hvad man opfattede som den "mørke middelalder". En pointe der naturligvis slet ikke ses hos Dante.

I forhold til sine forgæengere lægger Rodin i sine tidlige skitser til motivet mere vægt på lidelsen og gruen $\mathrm{i}$ forløbet, men bevarer dog stadig det oprejst heroiske udtryk. Man kan her forestille sig en vis påvirkning fra den antikke Laookon-gruppe, der jo fortæller en lignende historie om hvordan en far og hans sønner bukker under for en ikkemenneskelig, grum overmagt. En pennetegning, atter gengivet hos Pinet, viser figuren voldsomt slynget, oprejst $i$ Rodins karakteristiske ru ekspressivitet. Men altså netop stadig oprejst, så at sige knejsende til det sidste. Vi befinder os her endnu i den stoiske fase af forløbet, dvs. før børnenes død: ... alt i mig forstened.... Tegningen er ligesom søgende, på vej mod det endelige udtryk; man har nærmest indtryk af en variation over Carpeaux' Ugolino, et værk som Rodin beundrede. 
Rodins endelige version kan f.eks. ses i gipsafstøbning på Musée d'Orsay. Den bygger videre på skitserne, men er ved et enkelt greb gjort helt anderledes, idet figuren er lagt ned, så vi nu ser den allerede halvt blinde mand kravlende på børnenes døde kroppe: ...i blinde famled

jeg over deres lig, og kaldte på dem...

Skønt fremstillet i monumentalstørrelse, er Ugolino nu kommet i øjenhøjde med beskueren. Heroismen i figuren kommer indefra, ved ansigtsudtryk og kropslig ekspressivitet snarere end ved positur, ligesom tilfældet er $\mathrm{i}$ den tematisk beslægtede gruppe Borgerne fra Calais, der kan ses i bronceafstøbning på Glyptoteket, i salens forhøjede ende ved siden af Den fortabte sjel.

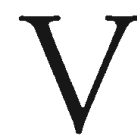
i går imidlertid nu forbi begge, ud af salen, og drejer to gange til venstre for at slutte af med Carpeaux' Ugolino og hans sonner i hungertårnet, som der står på plinten. Gruppen er fra 1861, Glyptotekets eksemplar fra 1873.

Det er slet ikke noget dårligt værk, på overgangen mellem romantik/ klassik og realisme. I forhold til Rodins

Artiklen er baseret på et foredrag 28.11.97 for Glyptotekets omvisere om Dantemotiver $i$ samlingerne.

hudløse ekspressivitet er Carpeaux' Ugolino dog stadig ret traditionelt heroisk: vi ser en person der, skønt anfægtet, behersker såvel sig selv som sine lidelsesfæller. Dette udtrykkes ikke blot i kropssproget, men især i gruppens helhed, hvor den voksne mand, idet han rager op over børnene, $i$ en fra kunstnerens hånd både stram og ganske levende pyramidekomposition:

$$
\text { Af smerte bed jeg begge mine }
$$

hander...

Skulpturen er anbragt til højre for trappen i den indvendige loggia på vinterhavens nordside, ved indgangen til den fortræffelige café. Her synes gæesternes madlyst ikke at anfægtes af den uhyggeligt-imposante terrakottagruppe, hvis titel og motiv måske ovenikøbet kan stimulere appetitten, hvis man nu og da skotter op til den mens man nyder stedets nøddemazarin, der i sig selv er besøget værd. Dog har muséets ledelse vist det hensyn at dreje Ugolino rundt, så han ikke som for et par år siden skal glo olmt mod buffeten og den kagekø der har det med at danne sig dér om søndagen.

Velbekomme!

Ole Meyers oversattelse of Den

Guddommelige Komedie skal udkomme på Hans Reitzels Forlag i 1999. 